\title{
The Effectiveness of Administrative Consolidation Processes in Urban Functional Areas. Case Studies from Poland and the USA
}

\author{
Marian Kachniarz ${ }^{1}$, Zbigniew Piepiora ${ }^{2}$ \\ 1Wroclaw University of Environmental and Life Sciences, Wroclaw, Poland, marian.kachniarz@upwr.edu.pl \\ 2 Wroclaw University of Environmental and Life Sciences, Wroclaw, Poland, zbigniew.piepiora@upwr.edu.pl
}

\begin{abstract}
Urban functional areas usually extend beyond the city's administrative boundaries. As a result, there is a problem of coordinating effective public service provision between the city and its suburbs. A review of world experience shows that two institutional solutions are usually applied here - intercommunal cooperation or adaptation of administrative borders to the scope of the functional zone. However, the studies so far have not provided an answer as to which method is more effective. The objective of the paper is to compare the processes of adapting administrative borders to urban functional areas. The hypothesis was formulated that uniform management of the entire functional area favors effectiveness and institutional sustainability of public service provision. Princeton in the USA and Lubin in Poland were selected as case studies. Princeton is an example of successful administrative consolidation of the city with the surrounding rural commune, while in Lubin, unfortunately, such a project was not implemented. In the conclusion was found that inter-communal cooperation does not provide sustainable solutions and is exposed to cadenza changes of decision-makers. The most effective seems to be the consolidation of individuals, but its success depends on a very well prepared and transparent procedure.
\end{abstract}

KEYWORDS: urban functional area, administrative consolidation, public services, inter-communal cooperation

\section{Introduction}

Administrative borders do not usually coincide with the functional impact zone of the cities. Urban functional areas extend beyond the administrative boundaries of the city. This situation has an impact on the organization of public services. The structure of these services and their quality should be continuous throughout the functional zone. As a result, there is a problem of coordination of effective public service provision between the city and its suburbs. Management in closed administrative boundaries of areas does not correspond to the real needs of the inhabitants and thus interferes with the regularity of the city development process. Therefore, there is a need for solutions that would eliminate these dysfunctions. A review of international experiences shows that two institutional solutions are usually used here - inter-municipal cooperation or the adaptation of administrative borders to the scope of a functional zone. However, the research so far has not provided a clear answer to the question of which method is more effective.

The aim of the study is to compare the processes of adaptation of administrative borders to urban functional areas on the example of two cities. One of them is Princeton in New Jersey (USA), which is an example of successful administrative consolidation of the city with the surrounding rural municipality. The second example is the Polish city of Lubin, where inter-communal cooperation was developed and the initiative to consolidate two administrative units has not yet been implemented. The analysis of these two separate cases, although they originate from other continents and countries, should prove the universal regularities that accompany the processes of managing functional zones.

Declarative inter-municipal cooperation is able to eliminate many problems and adapt the scope of tasks to the developing functional zones. However, in practice, there are few effective and stable examples of such actions. Sub-optimal solutions dominate, and their sustainability is largely based on leaders' personalities rather than institutional solutions. This results in a research hypothesis of this article expressing the conviction that uniform management of the entire functional area fosters efficiency and institutional sustainability of public service provision. Due to the fact that inter-communal cooperation does not provide sustainable solutions and is exposed to 
cadence changes of decision-makers, the most effective seems to be a consolidation of entities. In practice, this means that the changes in administrative boundaries should follow the changes in the functional zone. It is worth noting, however, that due to the inertia of administrative divisions, carrying out consolidation projects is not easy - their success often depends on a well-prepared procedure, long-term consultations, and transparency in presenting the results.

\section{Background}

The nature of many public tasks performed by local government units (LGU) often exceeds their administrative boundaries. These issues were dealt with in detail by Bennett (1997), distinguishing between administrative and functional space. Defining the relationships between these types of space, he distinguished three model situations, which are presented in the figure 1.

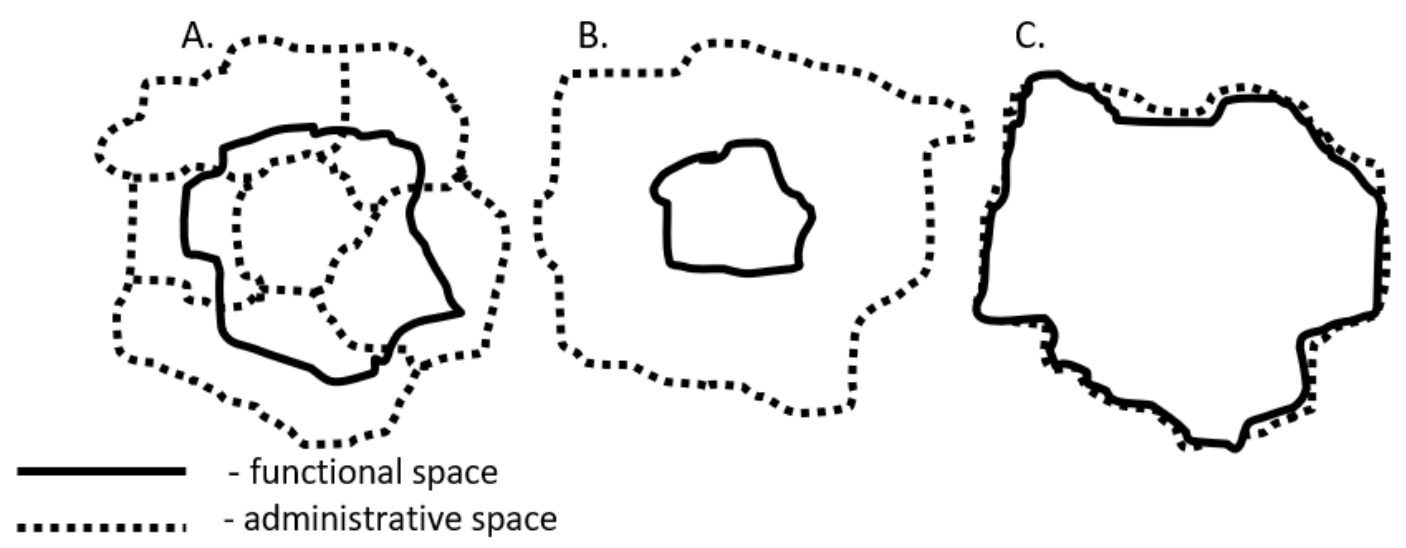

Figure. 1. The models of relations between administrative and functional space Source: Own elaboration based on Bennett (1997)

In the first model (A) small administrative structures divide a uniform functional space, in the second (B) the functional structure is entirely contained in the administrative unit and is much smaller than it is, and in the third model (C) administrative boundaries are adapted to social, economic and environmental functions. In practice, the third type of relationship is very rare, where there is a good relationship between administrative boundaries and gravitational zones. In the case of agglomeration systems, this is usually the first type where a smaller administrative space is included in a wider functional area. In this case, more efficient and effective provision of public services requires coordination of activities, institutional forms of cooperation, or changes in administrative boundaries.

A functional area is a geographically, spatially and economically coherent zone of city influence, based not only on the existence of functional links but also on advanced urbanization processes (Śleszyński 2013). According to the OECD (2013), urban functional areas are considered in terms of population density, which allows determining the city core and flow streams (a daily mobility variable) defining a suburban zone. In other words, it is a compact urban settlement system (core) and a functionally linked urbanized zone. This complex, economically, socially and spatially coherent area allows for the coordination of flows shaping the quality of life of residents (Yanqiang 2014; Przybyła, Kachniarz 2017; Hansen 1959). The scope of these flows, therefore, determines the cohesion limit of a given functional area. Its effective management requires an integrated and horizontal territorial approach. It optimizes costs, increases efficiency and rationalizes the prices of services provided, ensuring an efficient management process.

Such a research problem is the subject of many discussions, polemics, and research concepts. Representatives of the traditional school of metropolitan reforms, such as Stephens and Wilkstrom (2000), tend to favor formal solutions, i.e. LGU consolidation. Communalists', such as Ostrom, 
Tiebout, and Warren, (1961), based on the theory of public choice, believe that the situation can be controlled through inter-communal cooperation.

Looking at global trends over the last few decades, we can see a clear trend towards increasing the size of LGUs through their consolidation. In Europe, for example, this was diagnosed by Swianiewicz (2015), while in the USA, Faulk \& Hicks (2011). However, the results of research on the effects of these consolidations are not unambiguous. The assumed effect of scale and reduction of operating costs of LGU in ex-post studies is very difficult to demonstrate. Tavares (2018) carried out a broad review of the results of such studies.

The results of recent research undertaken in the USA (Caprio \& Pfeiffer 2014; Bel \& Warner 2015), the Netherlands (Allers \& Geertsema 2016), Denmark (Blom-Hansen et al. 2016) and in Poland (Kachniarz 2014) recommend cautious expectations rather than unbridled optimism, which often results from government reports. The effects of intercommunal cooperation are assessed in a similar way. Research conducted in the Netherlands (Allers \& de Greef 2018), France (Frère, Leprince, and Paty 2014) and the USA (White 2002) has shown that theoretical assumptions rarely bring results in practice. As Swianiewicz (2018) notes, such a shape of results may result from the fact that most of the reforms are forced in nature. There are relatively few bottom-up consolidations, voluntarily initiated by local authorities and communities. In such a case, conformism may be smaller and thus more beneficial. Swianiewicz points to a research gap concerning such projects, which this article tries to fill, albeit in part.

\section{Materials and methods}

In order to achieve this goal, in the first part of the research, the source materials were searched in order to reconstruct the history of spatial structure formation in Princeton (USA) and Lubin (Poland). In this way, the functional dynamics of cities were identified, along with the identification of the causes of these processes. In the second part, the literature and source materials concerning the process of designing and implementing consolidation projects in both cities were analyzed using the desk research method. On this basis, the course and nature of decision-making processes, which were the basis of these undertakings, were reconstructed. Particular attention was paid to the role of communication and consultation elements with local leaders and residents in the achievement of key decisions. All these elements were subjected to comparative analysis in order to sublimate the characteristics of each of the processes, which could become good universal practices.

A number of different primary and secondary sources have been used in these studies. These were mainly statistical databases aggregated in the Central Statistical Office's Local Data Bank (BDL GUS), City Data and New Jersey State Data Center (NJSDC). A great deal of information was also obtained from analyses and reports prepared in both cities to justify consolidation projects. In Princeton, it was primarily a study by the Consolidation Committee entitled: "Borough of Princeton and Township of Princeton Joint Consolidation/Shared Services" (Summary Report, 2011). In Lubin, in turn, the basis for the expert report was the "Functional and spatial conditions of Lubin's development." (Czamara et al. 2019). The basis for the evaluation of the effectiveness of these projects was the analysis of studies and evaluation reports prepared by various bodies. It included materials created by self-government executive boards, studies by independent experts and scientific analyses. In order to determine the moods accompanying these projects, a media analysis of press publications (e.g. New Jersey Monthly and Gazeta Wrocławska), information portals (e.g. njspotlight.com; lubin.pl) and radio and television programs (e.g. PCTV; NJTV; TVP3; Radio Wrocław) was carried out.

\section{Results and discussions}

The first subject of analysis is Princeton - a city and borough's located in New Jersey, USA. Princeton's municipalities had roughly similar demographics. The township's population of 16200 was comparable to the borough's 12300 . Princeton's municipalities had roughly similar demographics. The township's population of 16200 was comparable to the borough's 12300 . The 
town and the surrounding residential areas, by age, race, income, and average household size, were comparable.

The functioning of Princeton University, a leading university in the USA, makes the city stand out from other areas of New Jersey in many ways. The structure of employment is dominated by creative class - in terms of the population holding Master's and Ph.D. degrees, Princeton is ranked 4th in the entire United States. It is also one of the leading American cities with the highest percentage of the population working in educational professions and in the field of science. For this reason, average earnings, the value of a real estate or property tax revenues are also higher in this area. The power of attraction is manifested in daily migrations - commuters and service users account for almost $100 \%$ of the local population. The characteristic feature is that the urbanized functional zone developed independently of the historically shaped borders. An example was the university campus, which until the moment of consolidation was crossed by the border of these two communes.

The second subject of our analyses is Lubin - a city in the Lower Silesian Region in southwestern Poland. Lubin is the capital of the Copper Basin, with a large dominance of industrial functions (copper mining and metallurgy). With a population of around 80,000 and a rural municipality of 15,000 , the city is a much larger center than the surrounding rural areas. The urban sprawl processes diagnosed here are typical of many similar centers, so this case study can be representative of many European cities. In the case of Lubin, strong external suburbanization processes were defined, in which the city loses its inhabitants to the benefit of the neighboring communes. This is related to spatial effects ("spill-over" of the city), economic effects ("taxpayer relocation") and social effects ("elution" of active social groups from existing urban structures). The consequence is, clearly defined, difficulties in integrated management of this functional area. After 1988, despite the expansion of the functional zone, management remained within the former administrative boundaries. Earlier, along with the process of the spatial development of Lubin, its borders were also extended. As a result, the former rural areas underwent significant changes not only in terms of infrastructure but also in social terms. They constitute Lubin's residential base and their inhabitants are connected with the city by both work and daily migrations in order to fulfill their life functions. In both cases, therefore, the influence of the city is, in fact, wider than the administrative boundaries, which in many places seem rather random. Both in Princeton and Lubin, the LGU layout resembles boroughs doughnut hole, which was fully surrounded by the township.

Therefore, the question arises about the effectiveness of logistics of the entire functional area, which is the basis for its development processes. From the point of view of urban and social logistics, it is an area which allows for long-term shaping and coordination of appropriate organization of public services. Neither a city separated from its suburbs nor suburban areas separated from the city are able to meet such a condition. Only coherent management of a functional zone can combine these two potentials. It can take place in the form of cooperation between two local governments or administrative consolidation.

In both cases, attempts at joint management of services can be identified. In the case of Princeton, the municipalities already had many shared serviced (thirteen in all). Among the shared services ware animals control, common social service agency (The Corner House), the Fire Department, first aid and rescue, the Health Department, recreation, planning, and the library. In addition, the two municipalities shared some school district and the Open Space Found. The sharing services had a wide scope and a long tradition here.

The situation in Lubin was very different. Although cooperation was undertaken in many areas (e.g. education, communication, economic development, planning, municipal management), the practices of service sharing turned out to be surprisingly unstable. Many services were combined, then distributed, and after the next elections, they were combined again. These decisions were clearly influenced by cadences and the lack of mutual trust between the authorities. Many coordination initiatives have not avoided sub-optimal solutions, not only in terms of costs but also in terms of the quality of services offered to citizens. 
Therefore, it can be concluded that the initiative to consolidate communes in the case of Princeton appeared thanks to long-term cooperation in providing services, whereas in Lubin it was exactly the opposite - the problems in cooperation led to the idea of a merger. In both cases, however, the goal of consolidation was the same - elimination of problems of coordination of activities in the areas which were previously under different jurisdictions. It should be stressed that, despite the different circumstances of the consolidation decision, in both cases, it was a bottom-up decision that originated in the directly concerned LGUs. This is an important remark, as many consolidation reforms in the world are forced by central governments. In this case, the role of governments was limited to stimulating the process only. In the case of Princeton, the state of New Jersey declared to cover a significant part of the costs of the merger, while in the case of Lubin, the government provides a systemic incentive in the form of a financial bonus $(5 \%$ more share in the PIT for a period of 5 years). The proposals for consolidation in both cases were to be the same through the amalgamation of two communes and the establishment of one LGU. However, the process itself proceeded differently, which is why we are now dealing with different effects of the process.

In Princeton, such proposals were not new - the first time the consolidation question appeared on Princeton ballots was in 1953, when the proposal was soundly rejected in both the borough and township. Another consolidation referendum In 1979 passed In the township and was narrowly defeated in the borough. And in 1996, one more consolidation proposal failed by a thin margin In the borough while winning strong support in the township (Summary Report 2011). In the case of Poland, self-governing communes were established as a result of the reform in 1990. The first concrete proposals of the city concerning the merger appeared in 2003, unfortunately, they were unambiguously rejected by the rural commune. Again, the proposal was submitted by the city in 2011, after the change of authorities in the rural commune, and in 2015. Unfortunately, the commune reacted negatively to both proposals by creating a media narrative that the city wants to "annex" the rural commune. As you can see, Princeton's experiences were similar to those in Lubin, but the second case had a much shorter time horizon.

The key decisions to merge the two Princeton municipalities were taken in 2009 when Borough and Township's governing bodies initiated a process to explore the potential benefits of consolidating into a single municipality. A Commission of Borough and Township representatives was formed to examine the issue in depth. The Commission has produced several transparent reports presenting different versions of the solutions. Great emphasis was placed on reaching the citizens directly with objective information. It was like an election campaign. As a university town, Princeton boasts an abundance of intellectual capital, producing an unusually active and involved citizenry. This made it easier to staff the various volunteer commissions studying, promoting and enacting consolidation. For example one of typical consolidation study group held about 70 public meetings over 16 months, first to gather feedback and later to explain how consolidation would work (Municipal Consolidation 2013).

Throughout the whole process, expert support - Center for Governmental Research (CEG) was also used. Following nearly a year of intensive study, and working closely with the consultant (CGR), on 25 May 2011, the Commission adopted a resolution on the consolidation. In November 2011, voters in both the township and the borough decisively approved consolidation ballot questions. This past Jan. 1 2013, after a 13-month implementation process led by a transition task force, a new mayor and council took office and the new Princeton came into being (figure 2).

In the case of Lubin, the city submitted a proposal to merge the two communes in 2015, but the lack of consent of the rural commune authorities made it impossible to continue the process. Therefore, the municipality prepared analyses concerning the functional and spatial conditions of the city's development (Czamara et al. 2019). On this basis, in December 2018, the city council unilaterally adopted a resolution on including a part of the rural commune in the city (see figure 3 ). As you can easily guess, it caused a protest of the rural commune authorities, which would lose the most urbanized areas. They activated its inhabitants, who expressed their opposition to such a solution in consultations. There were also many demonstrations and a media campaign based on 
emotional accusations and not on factual arguments. In similar polls, the city residents were in favor of including these areas.

Despite this atmosphere, in March 2019 the city authorities applied to change their borders. According to the procedure in force in Poland, the final decision in such cases is taken by the central government. Thus, the game of changing borders has moved to the level of central politics, and more important than the opinions of local residents becomes the game of interests of major political parties. Unlike Princeton, where local decision-makers were very keen to support the residents, political power in Lubin counts in reaching the ear of the president of the ruling political party.
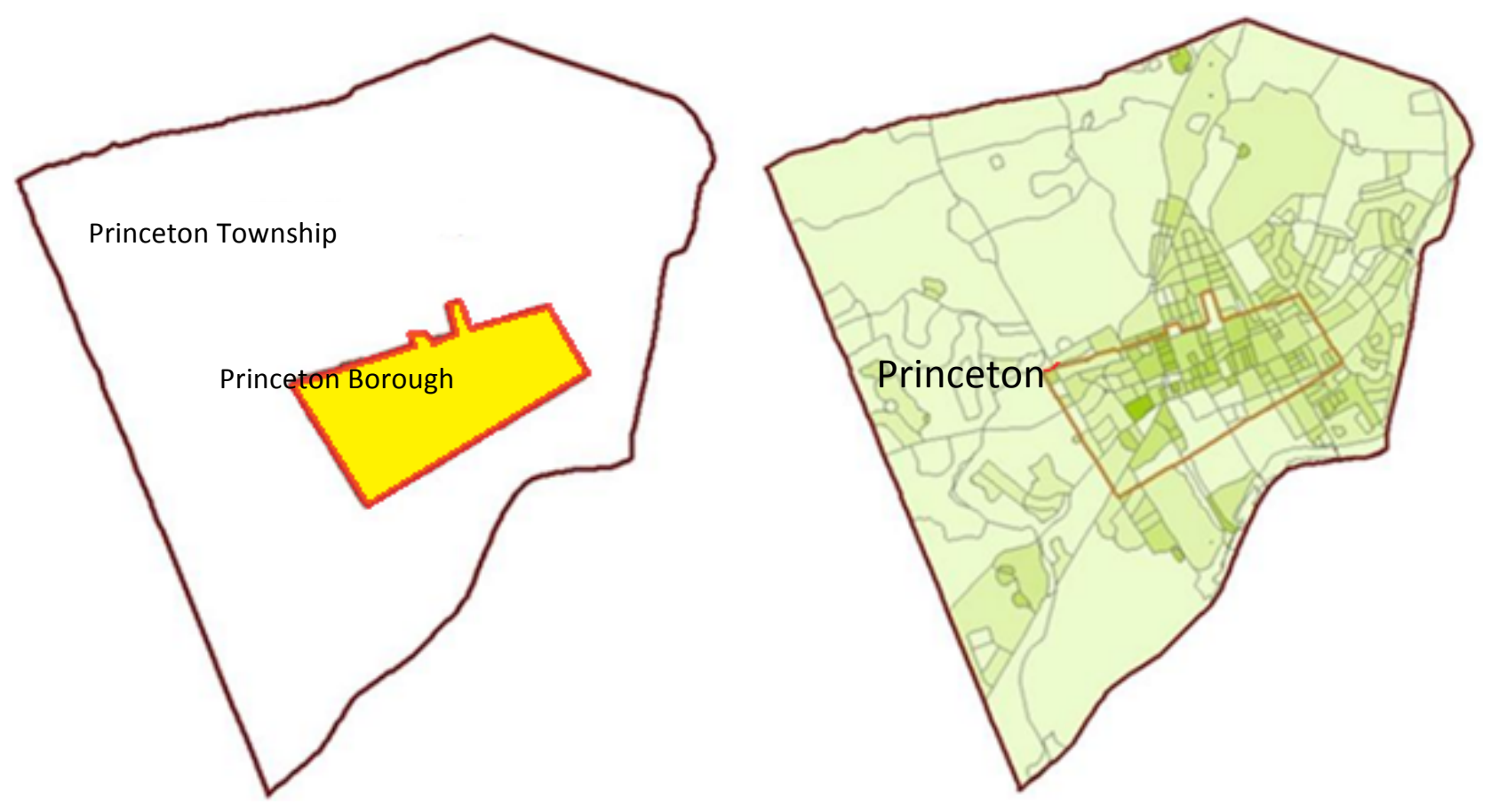

Figure 2. The Princeton's, pre- and post-consolidation Source: own elaboration based on (Summary Report, 2011)

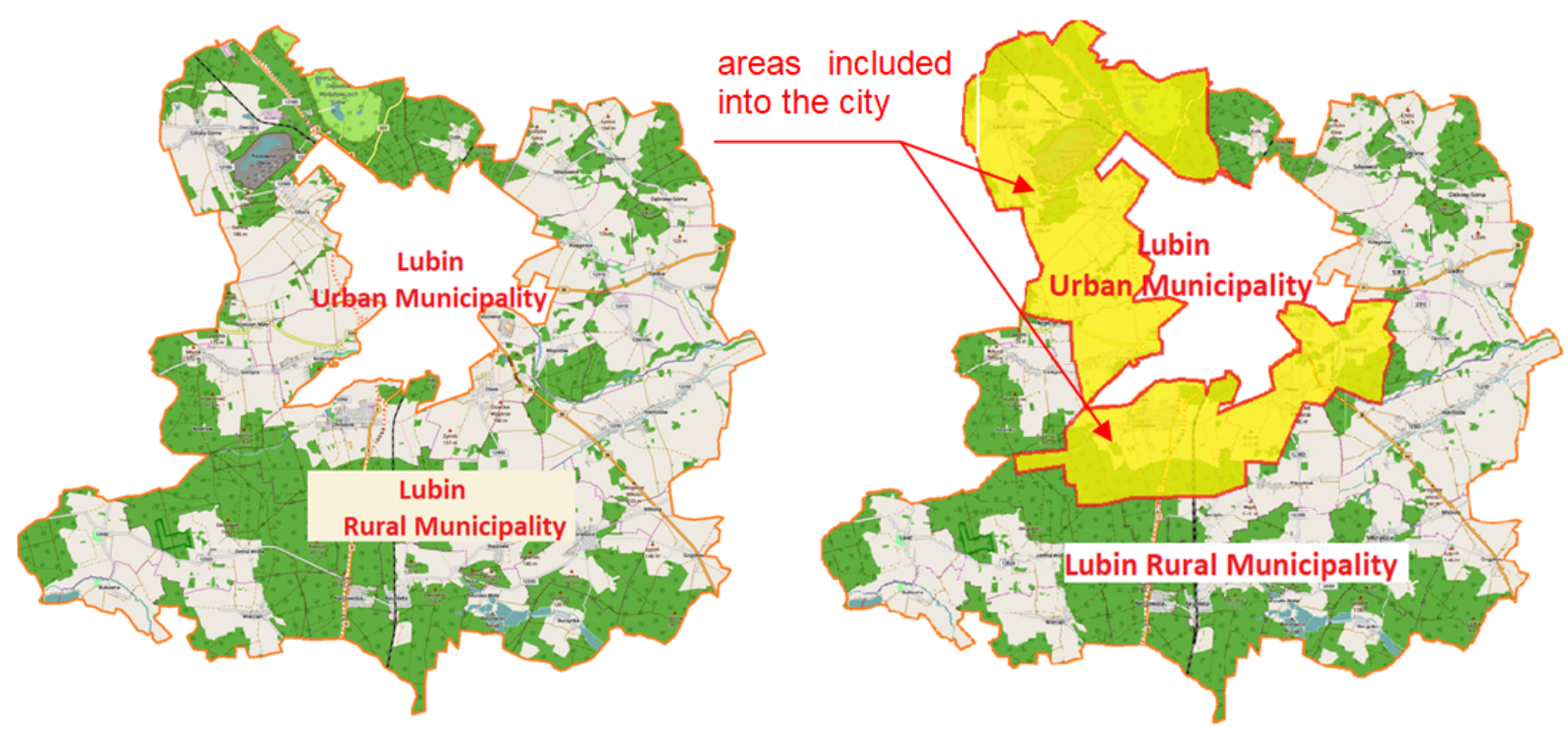

Figure 3. Lubin, pre- and post-consolidation Source: own elaboration 


\section{Conclusions}

Neither a city separated from its suburbs nor suburban areas separated from the city are able to meet condition the long-term shaping and coordination of appropriate organization of public services. Only coherent management of a functional zone can combine these two potentials. It can take place in the form of cooperation between two local governments or administrative consolidation. The cities that have been analyzed here are cases where problems of coordination in the functional zone have been solved through inter-communal cooperation. Both cases had different experiences, but both in Princeton and Lubin, it did not bring satisfactory results. Therefore, the research hypothesis adopted in the introduction that inter-communal cooperation does not provide sustainable solutions and is exposed to cadences changes of decision-makers has been confirmed, which makes the consolidation of entities seem to be the best solution. In practice, this means that the changes in administrative boundaries should follow the changes in the functional zone. This conclusion is also the result of a number of other studies (e.g. Voorn, Van Genugten and Van Thiel, 2017; Jochen, Klimovský and Pinterič. 2016; Bel and Warner 2015).

Therefore, the initiative to consolidate the municipalities in the Princeton case appeared despite the longstanding cooperation in the provision of services, whereas in Lubin it was exactly the opposite - short-term problems with cooperation led to the idea of a merger. In both cases, however, the objective of consolidation was the same - to eliminate coordination problems in areas that were previously located in different jurisdictions. In the article a comparative analysis of two such consolidation projects was carried out, adapting administrative borders to urban functional areas. In this way, the objective of the work, as set out in the introduction, was achieved. The results of the conducted works also allow formulating a few basic conclusions.

Firstly, in the light of the studies presented here, a more effective solution to the dilemma of using soft (communal cooperation) or hard instruments (changes in administrative borders) seems the use of the latter. The many years of cooperation at Princeton have not led to fully satisfactory solutions. In the case of Lubin, the cooperation was not sustainable and depended on the authorities cadence.

Secondly, consolidation reforms seem to be more effective if they are undertaken from the bottom up. Then there is a greater chance of conciliatory rather than forceful solutions. The former are able to make better use of local conditions, which are often underestimated by top-down solutions.

Thirdly, the only way to achieve consensus for consolidation is a very active and transparent social campaign with the ability to reach out to broad groups of stakeholders with reliable information. Otherwise, demagogic propaganda will fill this gap.

Fourthly and finally, as the Princeton case has shown, it is worthwhile to involve an objective consultant in the project. His task is to lead the process to success, which requires not only the preparation of documentation but also accompaniment in all stages of the project.

This case study is a clear signal to governments policy. Taking into account the institutional conditions, it can be assumed that it is even important from the point of view of international considerations concerning the management of functional areas.

\section{References}

Allers, Maarten A. and J.A. de Greef. 2018. "Intermunicipal cooperation, public spending and service levels." Local Government Studies 44 (1): 127-150. Doi: 10.1080/03003930.2017.1380630.

Allers, Maarten. A., and Bieuwe J. Geertsema. 2016. "The Effects of Local Government Amalgamation on Public Spending, Taxation, and Service Levels: Evidence from 15 Years of Municipal Consolidation." Journal of Regional Science 56: 659-682. Doi:10.1111/jors.2016.56.issue-4.

Bel, Germà, and Warner Mildred E. 2015. "Inter-Municipal Cooperation and Costs: Expectations and Evidence." Public Administration 93(1): 52-67. Doi:10.1111/padm.2015.

Bennett, R.J. 1997. “Administrative systems and economic spaces.” Regional Studies 3: 323-336.

Blom-Hansen, Jens, Kurt Houlberg, Søren Serritzlew and Daniel Treisman. 2016. "Jurisdiction Size and Local Government Policy Expenditure: Assessing the Effect of Municipal Amalgamation.” American Political Science Review 110: 812-831. Doi:10.1017/S0003055416000320. 
Caprio, Raphael J., Pfeiffer Marc H. 2014. Size May Not be the Issue: An Analysis of Cost of Local Government and Municipal Size in New Jersey, Local Government Research Centre, Edward J. Bloustein School of Planning and Public Policy, Rutgers University.

Czamara, Włodzimierz, Marian Kachniarz, Szymon Szewrański, Małgorzata Świąder, Magdalena Kalisiak-Mędelska. 2019. "Funkcjonalno-przestrzenne uwarunkowania rozwoju Lubina." Expert report, Wrocław.

Faulk, Dagney and Hicks Michael. 2011. Local Government Consolidation in the United States. Amherst, NY: Cambria Press.

Franzke, Jochen, Daniel Klimovský and Uroš Pinterič. 2016. "Does Inter-Municipal Cooperation Lead to Territorial Consolidation? A Comparative Analysis of Selected European Cases in Times of Crisis." In Local Public Sector Reforms in Times of Crisis: National Trajectories and International Comparisons, edited by Sabine Kuhlmann and Geert Bouckaert. 81-98. London: Palgrave Macmillan. Doi: 10.1057/978-1-137-52548-2_5.

Frère, Quentin, Matthieu Leprince, and Sonia Paty. 2014. "The Impact of Intermunicipal Cooperation on Local Public Spending." Urban Studies 51: 1741-1760. Doi:10.1177/0042098013499080.

Hansen, Walter G. 1959. "How Accessibility Shapes Land-use." Journal of the American Institute of Planners 25: 7376.

Kachniarz, Marian. 2014. "Kooperatywność samorządów lokalnych.” Research Papers of Wroctaw University of Economics 339: 36-48.

Municipal Consolidation Case Study. 2013. An Evaluation of the Princeton, NJ Borough-Township Consolidation Transition Process. 2013. Woodrow Wilson Schol of Public and International Affairs, Princeton University.

OECD. 2013. Definition of Functional Urban Areas (FUA) for the OECD metropolitan database.

Ostrom, Vincent, Tiebout Charles. M., Warren Robert. 1961. "The Organisation of Government in Metropolitan Areas: A Theoretical Inquiry.” American Political Science Review 55: 831-842.

Przybyła, Katarzyna., Kachniarz Marian. 2017. "The impact of administrative reform on the central functions of larger Polish cities." Journal of Economic Issues 51(3): 843-862.

Śleszyński, Przemysław. 2013. "Delimitacja Miejskich Obszarów Funkcjonalnych stolic województw." Przegląd Geograficzny 85 (2): 173-195.

Stephens, Ross G., Wikstrom Nelson. 2000. Metropolitan government and governance: theoretical perspective, empirical analysis, and the future. New York, Oxford: Oxford University Press.

Summary Report. 2011. Borough of Princeton and Township of Princeton Joint Consolidation/Shared Services Study Commission. Princeton.

Swianiewicz, Paweł. 2015. "Reformy terytorialne - europejskie doświadczenia ostatniej dekady." Samorząd Terytorialny 6: 7-22.

Swianiewicz, Paweł. 2018. "If territorial fragmentation is a problem, is amalgamation a solution? - Ten years later." Local Government Studies 44 (1): 1-10. Doi: 10.1080/03003930.2017.1403903.

Tavares, António F. 2018. "Municipal amalgamations and their effects: a literature review." Miscellanea Geographica. Regional Studies on Development 22 (1): 5-15. Doi: 10.2478/mgrsd-2018-0005.

Voorn, Bart, Marieke L. Van Genugten, and Sandra Van Thiel. 2017. "The efficiency and effectiveness of municipally owned corporations: a systematic review." Local Government Studies 43 (5): 820-841. Doi: 10.1080/03003930.2017.1319360.

White, Sammis. 2002. "Cooperation Not Consolidation: The Answer for Milwaukee Governance." Wisconsin Policy Research Institute Report 15, Milwaukee.

Yanqiang, Ma. 2014. City Logistics in China - An Empirical Study from an Emerging Market - Economy Country. Darmstadt: Technische Universität Darmstadt. 